\title{
Analisis kebutuhan pengeksplisitan hakikat sains (NOS) dalam bahan ajar pada topik lapisan bumi
}

\author{
Ella Putri Artifasari, Sri Rahayu*, Vita Ria Mustikasari \\ Universitas Negeri Malang, Jl. Semarang No. 5 Malang, Jawa Timur, Indonesia \\ *Penulis korespondensi, Surel: srirahayulestari@um.ac.id
}

Paper received: 01-02-2021; revised: 15-02-2021; accepted: 28-02-2021

\begin{abstract}
Science learning aims to realize students have the science literacy. One characteristic for someone who is science literate is having an understanding of NOS. NOS can be explicit in teaching material. based on various studies and observation results indicate that NOS exploration in teaching materials is still low so that it affects students' understanding of NOS. This research uses descriptive research method with data collection is done through literature study so that the result of need analysis explicit the nature of science (NOS) in teaching material on topics of layer of earth.
\end{abstract}

Keywords: teaching material; science literacy; the Nature Of Science (NOS).

\begin{abstract}
Abstrak
Pembelajaran IPA bertujuan mewujudkan siswa berliterasi sains. Salah satu karakteristik bagi seseorang yang berliterasi sains yaitu memiliki pemahaman tentang NOS. NOS dapat dieksplisitkan dalam bahan ajar. berdasarkan berbagai penelitian dan hasil observasi menunjukkan bahwa pengeksplisitan NOS dalam bahan ajar masih rendah sehingga mempengaruhi pemahaman siswa mengenai NOS. Penelitian ini menggunakan metode penelitian deskriptif dengan pengumpulan data dilakukan melalui studi literature sehingga dihasilkan analisis kebutuhan pengeksplisitan hakikat sains (NOS) dalam bahan ajar pada topik lapisan bumi
\end{abstract}

Kata kunci: bahan ajar; literasi sains; hakikat sains (NOS)

\section{Pendahuluan}

Pembelajaran IPA bertujuan mewujudkan siswa berliterasi sains (Lederman dkk, 2013). Literasi sains merupakan komponen penting dalam IPA (Holbrook \& Rannikmae, 2009). Literasi sains bersifat penting karena membantu siswa dalam menyikapi, menghadapi, dan mengambil keputusan untuk menyelesaikan permasalahan yang berhubungan dengan sains dalam kehidupan sehari-hari (Rahayu, 2014). Salah satu komponen penting dalam literasi sains yaitu Hakikat Sains (NOS) (Norris \& Philips, 2003).

Salah satu karakteristik bagi seseorang yang berliterasi sains yaitu memiliki pemahaman tentang NOS (Rahayu, 2014). NOS merupakan multikonsep yaitu historis, filosofis, sosiologis, dan psikologis yang sering didefinisikan sebagai ilmu epistemologi, karakteristik pengetahuan ilmiah, dan sumber ilmu pengetahuan. (Abd-El-Khalick, 2013; Bell, 2009; Lee, 2013). Sebagian besar penelitian mengindikasikan bahwa penerapan NOS secara eksplisit lebih efektif daripada secara impisit (Bell dkk, 2011). NOS yang diajarkan secara eksplisit dapat meningkatkan hasil belajar tentang materi sains, minat belajar sains, dan pengambilan keputusan terhadap masalah-masalah yang berhubungan dengan sains (Lederman, 2006; Bell dkk, 2011).

Penerapan NOS dapat dieksplisitkan dalam proses buku ajar, pembelajaran di kelas, maupun dalam Kurikulum (Rahayu, 2014). Pada Kurikulum 2013, salah satu pendekatan yang dianjurkan adalah pendekatan saintifik (permendikbud No 22 Tahun 2016). 
Pengekspisitan NOS pada pendekatan saintifik lebih efektif dalam proses pembelajaran (Lederman, 2006). Pembelajaran IPA membutuhkan alat bantu dalam proses pembelajaran. Salah satu kebutuhan penting dalam pembelajaran IPA yaitu bahan ajar. Bahan ajar dalam bentuk buku ajar dapat meningkatkan efisiensi dan efektifitas pembelajaran (Permendikbud No 22, 2016). Pengeksplisitan NOS dalam buku ajar bersifat penting karena pengetahuan siswa tentang NOS lebih banyak didapat dari buku teks (Aulia dkk, 2014).

Berdasarkan hasil penelitian Rusilowati tahun 2013 rata-rata persentase NOS yang muncul pada sembilan buku IPA SMP di Kabupaten Semarang sebesar 17,3\%. Berdasarkan hasil penelitian Aulia dkk, tahun 2014 menunjukkan bahwa secara umum tiga buku teks Biologi SMP di Kota Bandung sudah menyajikan ketujuh komponen hakikat sains tetapi lebih banyak menyajikan aspek teori dan hukum dalam sains dengan persentase sebesar $67 \%$. Hal tersebut mempengaruhi pengetahuan siswa mengenai NOS yang sebagian besar memiliki kategori rendah sebesar 56\%. Berdasarkan hasil observasi beberapa buku IPA SMP menunjukkan bahwa belum terdapat pengeksplisitan aspek NOS. Berdasarkan penelitian dan hasil observasi tersebut dapat diketahui bahwa bahan ajar yang beredar kurang memunculkan aspek NOS sehingga mempengaruhi pemahaman siswa mengenai NOS.

Salah satu topik dalam pembelajaran IPA yang ditemui dalam kehidupan sehari-hari sehingga bersifat sosio-saintifik yaitu lapisan bumi. Topik lapisan bumi terdapat dalam tes PISA bagian scientific knowledge pada content knowledge. Berdasarkan penelitian Melville tahun 2011 salah satu materi dalam topik lapisan bumi yaitu sejarah lempeng tektonik menyediakan banyak aspek NOS yang dapat meningkatkan pemahaman siswa terhadap aspek NOS. Dengan demikian topik lapisan bumi dapat dikembangkan menjadi bahan ajar yang dapat mengembangkan literasi sains siswa. Berdasarkan pemaparan di atas, perlu dikembangkan suatu bahan ajar IPA yang mampu mengembangkan literasi sains siswa. Pengembangan bahan ajar tersebut dapat ditempuh dengan mengeksplisitkan hakikat sains (NOS). Oleh karena itu diperlukan sebuah penelitian untuk menganalisis kebutuhan pengeksplisitan hakikat sains (NOS) dalam bahan ajar pada topik lapisan bumi.

\section{Metode}

Penelitian ini menggunakan metode penelitian deskriptif. Penelitian deskriptif adalah penelitian yang berusaha mendeskripsikan suatu gejala, peristiwa, kejadian yang terjadi pada saat sekarang yang digambarkan sebagaimanan mestinya (Sudjana \& Ibrahim, 1989: 64). Pengumpulan data pada penelitian ini dilakukan dengan studi literatur. Data yang diperoleh dalam penelitian ini adalah data kualitatif.

\section{Hasil dan Pembahasan}

Tujuan dari pembelajaran IPA yaitu untuk mewujudkan siswa berliterasi sains (Lederman dkk, 2013). Salah satu karakteristik yang diharapkan bagi seseorang yang memiliki literasi sains (scientific literacy) yaitu memiliki pemahaman tentang hakikat sains atau Nature of Science (NOS) (Rahayu, 2014). Literasi sains siswa yang diajarkan dengan mengeksplisitkan NOS meningkat dibandingkan dengan siswa yang diajar tanpa NOS secara eksplisit (Lederman, 2006). Pembelajaran dengan menggunakan pendekatan saintifik akan berlangsung secara efektif apabila disertai dengan pengeksplisitan NOS (Lederman, 2006).

Tujuan dari pembelajaran IPA yaitu untuk mewujudkan siswa berliterasi sains (Lederman dkk, 2013). Salah satu karakteristik yang diharapkan bagi seseorang yang memiliki literasi sains (scientific literacy) yaitu memiliki pemahaman tentang hakikat sains 
atau Nature of Science (NOS) (Rahayu, 2014). Literasi sains siswa yang diajarkan dengan mengekplesitkan NOS meningkat dibandingkan dengan siswa yang diajar tanpa NOS secara eksplisit (Lederman, 2006). Pembelajaran dengan menggunakan pendekatan saintifik akan berlangsung secara efektif apabila disertai dengan pengeksplisitan NOS (Lederman, 2006).

Pendekatan saintifik memiliki penekanan utama yang harus dilakukan guru di kelas. Penekanan pertama guru harus memunculkan pertanyaan-pertanyaan yang bisa diinvestigasi oleh siswa. Pertanyaan tersebut dapat diperoleh dari stimulus-stimulus yang diberikan guru dan mengandung konflik sehingga siswa diharapkan mampu untuk bertanya. Penekanan kedua yaitu melatih siswa menggunakan keterampilam proses. Peran guru dalam kegiatan ini sebagai fasilitator yang membimbing siswa dalam mengembangkan keterampilan yang dimilikinya. Penekanan yang ketiga yaitu guru mampu melatih siswa untuk bernalar dan berpikir kritis. Hal tersebut dapat diterapkan dalam kegiatan mengasosiasi. Penekanan yang keempat yaitu guru mampu melatih siswa untuk bekerja sama dengan siswa lain. Selain itu guru juga mampu membimbing siswa dalam melakukan keterampilan berkomunikasi dengan baik (Rahayu, 2014).

Hakikat sains (NOS) merupakan suatu multikonsep yang mencakup aspek sejarah, sosiologi, dan filosofi sains yang sering didefinisikan sebagai epistimologi sains, karakteristik pengetahuan saintifik, dan sains sebagai sumber pengetahuan (Abd-El-Khalick, 2013; Bell, 2009; Lee, 2013). NOS juga didefiniskan sebagai epistimologi sains yaitu ilmu pengetahuan sebagai cara mengetahui, atau nilai-nilai dan keyakinan yang melekat dalam pengembangan dan validasi pengetahuan ilmiah (Abd-El-Khalick \& Lederman, 2000).

Terdapat tujuh aspek NOS yang dapat diimplementasikan ke dalam kurikulum dan pembelajaran. Ketujuh aspek tersebut adalah (1) pengetahuan ilmiah bersifat tentatif (dapat berubah), (2) pengetahuan ilmiah berbasis empiris, (3) pengetahuan ilmiah bersifat subyektif (theory-laden), (4) pengetahuan ilmiah selalu menggunakan inferensi, imajinasi dan kreativitas manusia, (5) pengetahuan ilmiah terikat dengan aspek sosial budaya, (6) perbedaan pada pengetahuan ilmiah antara pengamatan (observation) dan inferensi (inference), dan (7) fungsi dan hubungan antara teori ilmiah dan hukum ilmiah (Bell dkk, 2000; Lederman, 2007). Hakikat sains (NOS) diimplementasi ke dalam kurikulum dan standar pendidikan oleh sebagian besar negara-negara didunia ke dalam proses pembelajaran, beberapa diantaranya yaitu Amerika Serikat, dan Turki (Melville, 2011; Demirbas \& Funda, 2012). Penelitian yang dilakukan oleh Demirbas dan Funda tahun 2012 menunjukkan bahwa pendekatan reflektif eksplisit memiliki efek positif dalam meningkatkan pandangan siswa terhadap NOS. Selain itu penelitian yang dilakukan oleh Khishfe dan Abd-ElKhalick tahun 2002 menunjukkan bahwa pendekatan penyelidikan yang eksplisit dan reflektif lebih efektif daripada pendekatan implisit yang berorientasi pada permintaan dalam meningkatkan konsepsi NOS siswa. Penelitian yang dilakukan oleh Melville, 2011 menyatakan bahwa pemahaman siswa tentang NOS secara eksplisit dan reflektif dengan kegiatan pendukung yang lebih terfokus pada aspek NOS lebih unggul daripada pendekatan eksplisit dan reflektif tanpa aktivitas pendukung. Penelitian yang dilakukan Koksal dkk, tahun 2014 menyatakan bahwa Explicit-Embedded-Reflective (EER) efektif dalam meningkatkan pemahaman siswa kelas sembilan mengenai NOS. Berdasarkan penelitian tersebut dapat disimpulkan bahwa cara terbaik dalam memahami hakikat sains yaitu dengan cara eksplisit. 
NOS yang diajarkan secara eksplisit dapat meningkatkan hasil belajar tentang materi sains, minat belajar sains, dan pengambilan keputusan terhadap masalah-masalah yang berhubungan dengan sains (Lederman, 2006; Bell dkk, 2011). Pemahaman terhadap NOS memiliki pengaruh penting dalam pengembangan literasi sains (Holbrook \& Rannikmae, 2009; Melville, 2011). Penerapan NOS dapat dieksplisitkan dalam proses pembelajaran di kelas, buku ajar maupun dalam kurikulum (Rahayu, 2014).

Pemahaman tentang NOS merupakan salah satu karakteristik yang diharapkan bagi seseorang yang memiliki literasi sains (Rahayu, 2014). Menurut Rahayu tahun 2014 literasi sains bersifat penting karena membantu siswa dalam menyikapi, menghadapi, dan mengambil keputusan untuk menyelesaikan permasalahan sains dalam kehidupan seharihari. Selain itu siswa dapat mengembangkan pengetahuan, keterampilan, dan menggunakan sains sebagai warga negara maupun sebagai seorang individu.

\section{Simpulan}

\section{Kesimpulan}

Berdasarkan hasil studi literatur, dapat disimpulkan bahwa diperlukan pengeksplisitkan hakikat sains (NOS) dalam bahan ajar topik lapisan bumi. pengeksplisitan NOS dalam bahan ajar harus sesuai dengan tujuan utama pembelajaran IPA yaitu mengembangkan literasi sains.

\section{Saran}

Saran diperlukan untuk menindaklanjuti penelitian. Saran untuk penelitian selanjutnya adalah melakukan pengeksplisitan hakikat sains (NOS) dalam bahan ajar topik lapisan bumi. Pengembangan seharusnya mengeksplisitkan lebih banyak aspekaspek hakikat sains (NOS) yang sesuai dengan materi, kegiatan, maupun fenomena dalam kehidupan sehari-hari).

\section{Daftar Rujukan}

Abd-El-Khalick, F. (2013). Teaching with and about nature of science, and science teacher knowledge domains. Science \& Education, 22(9), 2087-2107.

Abd-El-Khalick, F., \& Lederman, N. G. (2000). Improving science teachers' conceptions of nature of science: A critical review of the literature. International journal of science education, 22(7), 665-701.

Aulia, A. N. (2013). Analisis buku teks biologi smp di kota bandung berdasarkan hakikat sains (Doctoral dissertation, Universitas Pendidikan Indonesia).

Bell, R. L., Lederman, N. G., \& Abd-El-Khalick, F. (2000). Developing and acting upon one's conception of the nature of science: A follow-up study. Journal of Research in Science Teaching: The Official Journal of the National Association for Research in Science Teaching, 37(6), 563-581.

Bell, R. L. (2009). Teaching the nature of science: Three critical questions. Best Practices in Science Education, 22, 1-6.

Bell, R. L., Matkins, J. J., \& Gansneder, B. M. (2011). Impacts of contextual and explicit instruction on preservice elementary teachers' understandings of the nature of science. Journal of Research in Science Teaching, 48(4), 414-436.

Demirbas, M., \& Balci, F. (2012). The impact of the explicit reflective approach in teaching the nature of science upon Turkish students 'perceptions of science. International Journal of Asian Social Science, 2(8), 1255-1260. 
Holbrook, J., \& Rannikmae, M. (2009). The meaning of scientific literacy. International Journal of Environmental and Science Education, 4(3), 275-288.

Khishfe, R., \& Abd-El-Khalick, F. (2002). Influence of explicit and reflective versus implicit inquiry-oriented instruction on sixth graders' views of nature of science. Journal of Research in Science Teaching: The Official Journal of the National Association for Research in Science Teaching, 39(7), 551-578.

Lederman, N. G. (2006, June). Research on nature of science: reflections on the past, anticipations of the future. In Asia-Pacific Forum on Science Learning and Teaching (Vol. 7, No. 1, pp. 1-11). The Education University of Hong Kong, Department of Science and Environmental Studies.

Lederman, N. G. (2013). Nature of science: Past, present, and future. In Handbook of research on science education (pp. 845-894). Routledge.

Lederman, N.G. \& Schwartz, R. (2006). Exploring contextually-based views of NOS and scientific inquiry: What scientists say. National Association for Research in Science Teaching (NARST) Annual Conference. San Francisco, CA: National Association for Research in Science Teaching. (Online)

Lederman, N. G., Lederman, J. S., \& Antink, A. (2013). Nature of science and scientific inquiry as contexts for the learning of science and achievement of scientific literacy. International Journal of Education in Mathematics, Science and Technology, 1(3).

Lee, Y. H. (2013). A proposal of inclusive framework of the nature of science (NOS) based on the 4 themes of scientific literacy for K-12 school science. Journal of the Korean Association for Science Education, 33(3), 553-568.

Melville, M. (2011). Explicit teaching of the nature of science: A study of the impact of two variations of explicit instruction on student learning (Doctoral dissertation, Arizona State University).

Norris, S. P., \& Phillips, L. M. (2003). How literacy in its fundamental sense is central to scientific literacy. Science education, 87(2), 224-240.

Pisa, O. E. C. D. (2015). Draft science framework. 2014-07-17]

Pendidikan, P. M., \& Kebudayaan, R. I. (2016). No. 22 tahun 2016 tentang Standart Proses Pendidikan Dasar dan Menengah. Kementerian Pendidikan dan Kebudayaan Republik Indonesia.

Rahayu, S. (2014). Menuju masyarakat berliterasi sains: Harapan dan tantangan kurikulum 2013. In Seminar Nasional Kimia dan Pembelajarannya (pp. 27-40).

Rusilowati, A. (2014). Analisis buku ajar IPA yang digunakan di Semarang berdasarkan muatan literasi sains.

Sudjana. N \& Ibrahim (1989). Penelitian dan Penilaian Pendidikan. Bandung: Sinar Bumi. 